\title{
Genotype effect on carcass and meat quality of lambs finished in irrigated pastures in the semiarid Northeastern Brazil
}

[Efeito do genótipo sobre características de carcaça e qualidade da carne de cordeiros terminados em pastagem irrigada no semiárido do Nordeste do Brasil]

\author{
G.A. Fernandes Júnior ${ }^{1}$, R.N.B. Lôbo ${ }^{2 *}$, M.S. Madruga ${ }^{3}$, A.M.B.O. Lôbo ${ }^{2}$, L.S. Vieira ${ }^{2}$, O. Facó ${ }^{2}$ \\ ${ }^{1}$ Universidade Estadual Paulista - Jaboticabal, SP \\ ${ }^{2}$ Embrapa Caprinos e Ovinos - Sobral, CE
}

\begin{abstract}
The aim of this study was to compare four genetic groups of sheep on the carcass and meat quality traits. Thirty-three contemporary and unrelated male lambs, all of single birth were used in the experiment, being thirteen from the Santa Inês (SI) breed, seven from the Brazilian Somali breed (BS), six from the Morada Nova (MN) breed and seven from the 1/2 Dorper - 1/2 Morada Nova (F1) crossbreed. The genotypes SI, BS and F1 presented similar performances in relation to hot and cold carcass weights, which values were $10.76 \pm 0.53 \mathrm{~kg}$ and $10.46 \pm 0.52 \mathrm{~kg}$ for SI, $9.20 \pm 0.73 \mathrm{~kg}$ and $8.99 \pm 0.71 \mathrm{~kg}$ for BS, and $9.35 \pm 0.73 \mathrm{~kg}$ and $9.13 \pm 0.71 \mathrm{~kg}$ for $\mathrm{F} 1$, respectively. The BS had a better hot carcass yield $(47.10 \pm 0.88 \%)$ and cold carcass yield $(46.00 \pm 0.87 \%)$. Better carcass conformation was observed in SI and F1 $(2.73 \pm 0.12$ and $2.50 \pm 0.17$, respectively) while the BS presented a better finishing $(3.29 \pm 0.20)$. The average for the rib eye area (REA) was $9.94 \pm 0.49 \mathrm{~cm}^{2}, 8.66 \pm 0.67 \mathrm{~cm}^{2}, 7.18 \pm 0.72 \mathrm{~cm}^{2}$ and $9.8 \pm 0.67 \mathrm{~cm}^{2}$, and for the carcass compactness index $(\mathrm{CCI})$ it was $0.17 \pm 0.01 \mathrm{~kg} / \mathrm{cm}, 0.17 \pm 0.01 \mathrm{~kg} / \mathrm{cm}, 0.11 \pm 0.01 \mathrm{~kg} / \mathrm{cm}$ and $0.16 \pm 0,01 \mathrm{~kg} / \mathrm{cm}$, for SI, SB, MN and F1, respectively. There were no significant differences between SI, BS and F1 regarding REA and CCI. Although, in general, the MN presented a relatively lower performance than the other genotypes, this breed had similar carcass yields and fat thickness when compared to SI and F1 and similar conformation and REA in comparison to the BS. Regarding meat quality, no differences were observed between genotypes, except for redness and cooking losses. It is concluded that no one group had a higher or lower performance in all traits analyzed. Moreover, for the management conditions employed in this study, there was evidence of greater specialization in meat production for genotypes SI, BS and F1 when compared to $\mathrm{MN}$, although there are no substantial differences between the four groups regarding meat quality.
\end{abstract}

Keywords: carcass yields, commercial cuts, shear force

\section{RESUMO}

O objetivo deste estudo foi comparar quatro grupos genéticos de ovinos quanto às características de carcaça e de qualidade da carne. Trinta e três cordeiros, contemporâneos, nascidos de parto simples e sem relação de parentesco, foram utilizados no experimento, sendo 13 da raça Santa Inês (SI), sete da raça Somalis Brasileira (SB), seis da raça Morada Nova (MN) e sete 1/2 Dorper - 1/2 Morada Nova (F1). Os genótipos SI, SB e F1 apresentaram desempenhos similares quanto ao peso das carcaças quente e

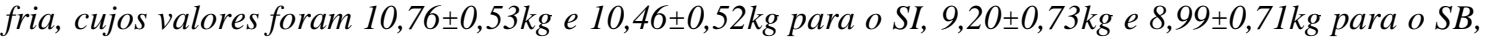

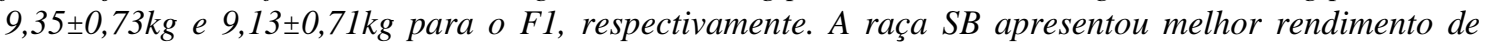
carcaça quente $(47,10 \pm 0,88 \%)$ e de carcaça fria $(46,00 \pm 0,87 \%)$. Os genótipos SI e F1 apresentaram melhores conformações $(2,73 \pm 0,12$ e 2,50 $\pm 0,17$, respectivamente), enquanto o SB apresentou melhor acabamento $(3,29 \pm 0,20)$. As médias para área de olho de lombo (AOL) foram 9,94 $\pm 0,49 \mathrm{~cm}^{2}$, $8,66 \pm 0,67 \mathrm{~cm}^{2}, 7,18 \pm 0,72 \mathrm{~cm}^{2}$ e $9,8 \pm 0,67 \mathrm{~cm}^{2}$ e para o índice de compacidade da carcaça (ICC) foram

Recebido em 23 de março de 2012

Aceito em 7 de maio de 2013

* Autor para correspondência (corresponding author)

E-mail: raimundo.lobo@embrapa.br 


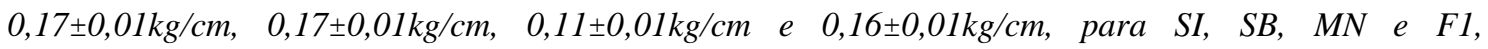
respectivamente. Não houve diferença significativa entre os genótipos SI, SB e F1 quanto à AOL e ao ICC. Apesar de, no geral, a raça MN apresentar desempenho relativamente inferior aos demais genótipos quanto às características de carcaça analisadas, essa raça apresentou rendimentos de carcaça e espessura de gordura similar ao SI e F1 e conformação e AOL similar ao SB. Não houve um grupo superior ou inferior para todas as características analisadas. Por outro lado, para as condições de manejo empregadas neste estudo, evidenciou-se maior especialização para produção de carne dos genótipos SI, SB e Fl em relação ao grupo MN. Não houve diferenças importantes entre os diferentes genótipos quanto à qualidade da carne.

Palavras-chave: rendimentos de carcaça, cortes comerciais, força de cisalhamento

\section{INTRODUCTION}

The ethnic types and native breeds are the basis of the genetics population of sheep in Northeastern Brazil. In this region, the food base of the sheep is the pasture, whether native or cultivated, and these genotypes are known for their adaptive and hardiness traits which allow them to make great use of the pasture under climatic conditions peculiar to the place. The Santa Inês, Brazilian Somalis and Morada Nova breeds, and the crossbred Dorper breed are among the main genetic groups bred in this region. However, despite being bred for meat, little is known about the carcass and meat quality traits in finishing these animals on pasture. Thus, determining the genotype effects on these traits could be an important step towards the establishment of the various uses of local breeds, according to the production system and marketing objectives.

In the sheep meat industry it is favorable to have animals that produce heavy carcasses, with good conformation, high proportion of muscles and adequate amounts of fat (Sousa et al., 2009), but which also present higher yields in prime cuts, hence, a carcass with a higher commercial value (Cezar and Sousa, 2007). Furthermore, it is known that nowadays the demand for quality products is growing and, as described in literature (Bressan et al., 2001; Bonagurio et al., 2003; Pinheiro et al., 2009), meat quality has been examined using $\mathrm{pH}$, color, water holding capacity, cooking losses and tenderness parameters.

Both carcass traits and meat quality are classified as quantitative traits, being influenced by genetic and environmental factors (Okeudo and Moss, 2005). The genotype influence study is important to improve productivity since the environment can be controlled to some extent. And, assuming that different environments interact differently with each genotype, it is recommended to study the influence of local genotypes on these traits in the environment where they will be raised and under management conditions closer to commercial systems.

According to Sañudo et al. (1997), the investigation on the carcass and meat quality aspects of local breeds and their crosses with exotic breeds can identify different possible schemes for the use of these breeds. Therefore, the objective of this study was to compare the performance of the Santa Inês, Morada Nova, Brazilian Somali and 1/2 Dorper - 1/2 Morada Nova genetic groups in relation to carcass characteristics and the commercial cuts and traits related to meat quality in a finishing system on an irrigated pasture in the semiarid Northeast of Brazil.

\section{MATERIALS AND METHODS}

The trial was carried out at the Brazilian Agricultural Research Corporation (EMBRAPA) in the Embrapa Goats and Sheep research unit, located in a semiarid region, $34^{\circ} 2^{\prime}$ south latitude and $40^{\circ} 21^{\prime}$ west longitude, at an altitude of $83 \mathrm{~m}$. The region is classified under the Köppen system as a BSH'w-type, i.e., mesothermal with summer and autumn rains. The rainy season occurs from January to June, and the dry season from July to December. The average annual temperature is $30^{\circ} \mathrm{C}$ and annual rainfall is $800 \mathrm{~mm}$.

Thirty-three contemporary and unrelated male lambs were used in the experiment, being thirteen from the Santa Inês (SI) breed, seven from the Brazilian Somali (SB) breed, six from the Morada Nova (MN) breed and seven from the $1 / 2$ Dorper - $1 / 2$ Morada Nova (F1) crossbreed. 
All lambs were of simple birth and received the same pre-weaning management under a semiintensive system on native pasture. After weaning, at an average age of $94 \pm 7.5$ days, the lambs were housed in paddocks made of Panicum maximum cv. Tanzania and given water and mineral salt ad libitum. They were supplemented once a day with concentrate $(48 \%$ - corn; $35 \%$ - cottonseed meal; $15 \%$ - soybean; $1 \%$ - limestone; $1 \%$ - mineral salt) at a rate of $1.5 \%$ body weight. The occupation period of each paddock was five days. The duration of the trial was 106 days.

The slaughter was carried out at the end of the experiment when the animals were around $200 \pm 7.5$ days old and after fasting for approximately twenty-four hours on a solid diet and twelve hours on a liquid diet. The animals were then weighed to obtain the slaughter weight (SW), then immediately underwent mechanical desensitization in the atlanto-occipital region, the jugular veins and carotid arteries were then severed for bleeding. After skinning and evisceration, the carcasses were separated in tarsometatarsus and carpometacarpal joints and weighed, obtaining the hot carcass weight $(\mathrm{HCW})$ and its yield (HCY $=\mathrm{HCW} / \mathrm{SW} \times 100)$. After 24 hours in a cold chamber at $4{ }^{\circ} \mathrm{C}$, the carcasses were weighed again to obtain the cold carcass weight $(\mathrm{CCW})$ and its yield $(\mathrm{CCY}=$ $\mathrm{CCW} / \mathrm{SW} \times 100)$, as well as the drip loss $(\mathrm{DL}=$ (HCW-CCW)/HCW x 100).

Visual scores ranging from one to five, with variations of 0.25 were assigned to evaluate the carcass conformation and finishing. Score one corresponds to bad conformation and poor finishing and score five corresponds to excellent conformation and excessive finishing. To reach a score, the carcasses were hung by the calcaneus tendon and positioned so that the tibias remained parallel. For the visual evaluation, emphasis was placed on the anatomical regions corresponding to the rump, leg (ham), loin and scapula, as well as thickness and distribution of the muscular and fat plans on the skeleton.

The following measurements were taken on the left half of the carcass: internal carcass length (ICL), which is the maximum distance between the front edge of the ischium-pubic symphysis and anterior edge of the first rib at its midpoint; leg length (LL), which is the distance between the perineum at its distal edge, and the inner edge of the tarsometatarsus joint on the inner side of the leg; the leg perimeter (LP), taken from around the leg; and thorax depth (TD), which is the maximum distance between the sternum and dorsum of the carcass from the sixth thoracic vertebra.

The carcass half was then cut according to the commercial cuts recommended by the Embrapa Goats and Sheep Unit: leg (ham) - cut between the last lumbar vertebra and first sacral vertebra; loin - cut between the $13^{\text {th }}$ thoracic vertebra and the last lumbar vertebra; rib - cut between the $5^{\text {th }}$ and $13^{\text {th }}$ rib; shoulder with ribs - split between the $1^{\text {th }}$ and $5^{\text {th }}$ thoracic vertebra; breast and flap cut straight, starting from the flank to the scapular-humeral; and neck - correspond to cervical vertebrae. The respective weights and yields of these cuts were recorded. The commercial yield of each cut was obtained in relation to the weight of the reconstituted carcass half.

The rib eye area (REA) was evaluated by a cross-section between the $12^{\text {th }}$ and $13^{\text {th }}$ rib, exposing the transversal section of the Longissimus dorsi muscle. The maximum length (A) and maximum depth (B) were measured using measuring tape and used in the formula: $\mathrm{LMA}=(\mathrm{A} / 2 * \mathrm{~B} / 2) \pi$, proposed by Silva Sobrinho (1999). The subcutaneous fat thickness (FT) was measured with a caliper ruler. The compactness carcass index was obtained from the ratio between the cold carcass weight $(\mathrm{CCW})$ and the internal carcass length (ICL). The compactness leg index was obtained from the ratio between the leg weight and its length (Cezar and Sousa, 2007).

Meat quality evaluations were assessed on the Longissimus dorsi muscle. $\mathrm{pH}$ values were taken immediately after slaughter ( $\mathrm{pH} 0)$ and 24 hours post-mortem (pH24) using a DM 20-Digmed ${ }^{\circledR}$ portable pot with electrode penetration with a precision of $0.001 \mathrm{pH}$ units. The apparatus was calibrated with a buffer solution at $\mathrm{pH} 7.0$ and $\mathrm{pH}$ 4.0. To insert the electrode the muscle was cut with a scalpel and cleaned with neutral soap and distilled water after each reading.

To analyze the meat qualities, the Longissimus dorsi muscle was wrapped in aluminum foil and 
plastic film, labelled and frozen at $-20^{\circ} \mathrm{C}$. The qualities evaluated were color, water holding capacity (WHC), cooking losses (CL) and shear force $(\mathrm{CF})$. This was performed at the "Laboratório de Análises Químicas de Alimentos - Universidade Federal da Paraíba".

To evaluate color the Minolta Chroma Meter CR 300 colorimeter was used at standard calibration. The samples were exposed to atmospheric air for 30 minutes and measurements were taken at three different points (Abularach et al., 1998). The rating system used was the CIELAB, in which $\mathrm{L}^{*}$ corresponds to the intensity of lightness, $\mathrm{a}^{*}$ corresponds to the redness and $\mathrm{b}^{*}$ corresponds to the values for yellow intensity. The following conditions were used: $8^{\circ}$ viewing angle, illuminant D65, and $10^{\circ}$ observer angle, which included a specular component.

The water-holding capacity (WHC) in the unprocessed meat was determined by the pressure method proposed by Grau and Hamm (1953). Previously crushed samples of Longissimus dorsi were used to analyze (twice) the WHC. The filter paper was pre-dried in a stove for 24 hours. Each sample had an initial weight of $0.5 \mathrm{~g}$ (IW) and was placed between two filter papers under a $5 \mathrm{~kg}$ press for 10 minutes to obtain the final weight $(\mathrm{FW})$ of the sample. The WHC was obtained from the following formula:

$$
\mathrm{WHC}=100-[(\mathrm{IW}-\mathrm{FW}) / \mathrm{IW} \times \% \mathrm{UMI}]
$$

where $\mathrm{WHC}=$ water holding capacity; IW = initial weight; $\mathrm{FW}=$ final weight; \%UMI = percentage of moisture in the sample.

Duplicate samples, with dimensions of $2.5 \mathrm{~cm} \mathrm{x}$ $1.3 \mathrm{~cm} \times 1.3 \mathrm{~cm}$, were used for the analysis of cooking losses (CL). Each sample was weighed on an analytical scale (0.001g accuracy) and placed in heat resistant plastic bags with a thermocouple attached to the geometric center (control of the cold spot) and then taken to a boiling water bath $\left(100^{\circ} \mathrm{C}\right)$ constantly stirring, with the opening of the bag above the water. The sample was boiled until the temperature of the cold spot reached $75^{\circ} \mathrm{C}$, at which time it was transferred to an ice bath $\left(1\right.$ to $\left.5^{\circ} \mathrm{C}\right)$ to achieve balance while still in the plastic bag and with the thermocouple attached. The sample was then dried with a paper towel and weighed again.
Cooking loss was expressed as being the percentage of weight loss related to the initial weight (Honikel, 1998). After the final weighing to calculate the CL, the samples were taken to the texturometer TA-XT2i (Stable Micro Systerm, Surrey, England), equipped with a Warner Bratzler blade, operating at $20 \mathrm{~cm} / \mathrm{min}$ to measure the peak of shear force, expressed in $\mathrm{kgf} / \mathrm{cm}^{2}$ (Duckett et al., 1998).

Statistical analyses were performed using the Statistical Analysis System (SAS Institute Inc, 1996) using a completely randomized design with four genotypes. Least square means were obtained using the SAS Proc GLM procedure and the t-test was used to compare means.

\section{RESULTS AND DISCUSSION}

There was a significant effect of the genotype on all carcass traits analyzed $(\mathrm{P}<0.05$; Tab. 1$)$. The genotype explained $52.8 \%, 44.37 \%$ and $43.8 \%$ of the total variation in slaughter weight $(\mathrm{SW})$, hot carcass weight (HCW) and cold carcass weight $(\mathrm{CCW})$, respectively. The higher $\mathrm{SW}$ of the Santa Ines breed confirms its higher growth rate when compared to the Brazilian Somali and Morada Nova breeds. However, the higher SW of the Santa Ines didn't mean a higher HCW. As for this trait and the $\mathrm{CCW}$ trait, the results were the same between genotypes, except in the Morada Nova breed which showed lower values.

The HCW is important because usually the producer is paid per kilogram of carcass produced. For the conditions employed in this study, Santa Inês, Brazilian Somali and F1 genotypes showed similar results. However, when considering the carcass yield, the Brazilian Somali breed had a better average than the other genotypes $(\mathrm{P}<0.05)$. Being of medium size and very compact, with a unique adaptive trait, the BS breed has a characteristic of depositing large amounts of fat in specific parts of the body, especially in the rump and tail, which acts as an energy reserve during times of food shortages. The medium size and compact aspect can be an indication of lower weight in non-carcass components, as denoted in the lower gastrointestinal tract weight (Tab. 1). The tendency to accumulate fat in the carcass instead of the gastrointestinal tract would explain the better yield. 
Table 1. Least-square means and respective standard errors for carcass traits in different genetic groups finished in irrigated pasture

\begin{tabular}{|c|c|c|c|c|c|}
\hline & \multicolumn{4}{|c|}{ Genetic group } & \multirow{2}{*}{ CV\% } \\
\hline & Santa Inês & Somalis & Morada Nova & F1 & \\
\hline SW (kg) & $23.98 \pm 0.96 a$ & $19.54 \pm 1.31 b$ & $14.38 \pm 1.41 \mathrm{c}$ & $20.82 \pm 1.31 \mathrm{ab}$ & 16.80 \\
\hline $\mathrm{HCW}(\mathrm{kg})$ & $10.76 \pm 0.53 a$ & $9.20 \pm 0.73 a$ & $6.20 \pm 0.78 b$ & $9.35 \pm 0.73 a$ & 20.65 \\
\hline CCW (kg) & $10.46 \pm 0.52 \mathrm{a}$ & $8.99 \pm 0.71 \mathrm{a}$ & $6.04 \pm 0.77 b$ & $9.13 \pm 0.71 \mathrm{a}$ & 20.81 \\
\hline GTW (kg) & $6.05 \pm 0.22 \mathrm{a}$ & $4.51 \pm 0.28 b c$ & $3.76 \pm 0.31 \mathrm{c}$ & $5.17 \pm 0.28 b$ & 14.79 \\
\hline $\mathrm{HCY}(\%)$ & $44.62 \pm 0.64 b$ & $47.10 \pm 0.88 \mathrm{a}$ & $42.69 \pm 0.95 b$ & $44.55 \pm 0.88 b$ & 5.17 \\
\hline $\mathrm{CCY}(\%)$ & $43.38 \pm 0.64 b$ & $46.00 \pm 0.87 a$ & $41.60 \pm 0.94 b$ & $43.47 \pm 0.87 b$ & 5.26 \\
\hline $\mathrm{DL}(\%)$ & $2.78 \pm 0.11 \mathrm{a}$ & $2.35 \pm 0.15 b$ & $2.55 \pm 0.17 \mathrm{ab}$ & $2.42 \pm 0.15 \mathrm{ab}$ & 15.76 \\
\hline Conformation & $2.73 \pm 0.12 \mathrm{a}$ & $1.86 \pm 0.17 b$ & $1.58 \pm 0.18 b$ & $2.50 \pm 0.17 \mathrm{a}$ & 19.67 \\
\hline Finishing & $1.62 \pm 0.15 b$ & $3.29 \pm 0.20 \mathrm{a}$ & $1.08 \pm 0.22 \mathrm{c}$ & $2.00 \pm 0.20 \mathrm{~b}$ & 27.23 \\
\hline $\operatorname{REA}\left(\mathrm{cm}^{2}\right)$ & $9.94 \pm 0.49 a$ & $8.66 \pm 0.67 \mathrm{ab}$ & $7.18 \pm 0.72 b$ & $9.8 \pm 0.67 \mathrm{a}$ & 19.26 \\
\hline FT (mm) & $1.65 \pm 0.80 \mathrm{ab}$ & $2.30 \pm 1.10 \mathrm{a}$ & $1.18 \pm 0.40 \mathrm{~b}$ & $1.37 \pm 0.46 b$ & 46.69 \\
\hline $\mathrm{CCI}(\mathrm{kg} / \mathrm{cm})$ & $0.17 \pm 0.01 \mathrm{a}$ & $0.17 \pm 0.01 \mathrm{a}$ & $0.11 \pm 0.01 \mathrm{~b}$ & $0.16 \pm 0.01 \mathrm{a}$ & 16.02 \\
\hline LCI $(\mathrm{kg} / \mathrm{cm})$ & $0.04 \pm 0.00 \mathrm{a}$ & $0.04 \pm 0.00 \mathrm{a}$ & $0.02 \pm 0.00 \mathrm{~b}$ & $0.03 \pm 0.00 \mathrm{a}$ & 17.79 \\
\hline $\mathrm{ICL}(\mathrm{cm})$ & $60.64 \pm 1.21 \mathrm{a}$ & $54.40 \pm 1.65 b c$ & $52.77 \pm 1.78 c$ & $58.09 \pm 1.65 \mathrm{ab}$ & 7.60 \\
\hline $\mathrm{TD}(\mathrm{cm})$ & $25.68 \pm 0.55 a$ & $23.16 \pm 0.75 b$ & $22.50 \pm 0.89 b$ & $23.94 \pm 0.75 \mathrm{ab}$ & 8.20 \\
\hline $\mathrm{LC}(\mathrm{cm})$ & $33.12 \pm 0.78 \mathrm{a}$ & $34.93 \pm 1.06 \mathrm{a}$ & $27.33 \pm 1.15 b$ & $32.67 \pm 1.06 \mathrm{a}$ & 8.69 \\
\hline $\mathrm{LL}(\mathrm{cm})$ & $49.64 \pm 0.83 a$ & $41.57 \pm 1.13 b$ & $41.15 \pm 1.23 b$ & $43.51 \pm 1.13 b$ & 6.66 \\
\hline
\end{tabular}

$\mathrm{SW}=$ slaughter weight; HCW = hot carcass weight; $\mathrm{CCW}=$ cold carcass weight; GTW = gastrointestinal tract weight; $\mathrm{HCY}=$ hot carcass yield, $\mathrm{CCY}=$ cold carcass yield; $\mathrm{DL}=$ drip losses; $\mathrm{REA}=$ rib eye area; $\mathrm{FT}=$ fat thickness; $\mathrm{CCI}=$ carcass compactness index; $\mathrm{LCI}=$ leg compactness index; $\mathrm{ICL}=$ internal carcass length; $\mathrm{TD}=$ thorax depth; $\mathrm{LC}=$ leg circumference; $\mathrm{LL}=$ leg length;

Means in row followed by same letter do not differ by $t$ test $(p>0.05)$; F1 $=1 \frac{1}{2}$ Dorper $x 1 / 2$ Morada Nova; CV = coefficient of variation

The drip loss (DL) is related to the amount and disposition of fat throughout the carcass. The fat acts as a protective cover at the time of cooling which prevents a high DL, resulting in a well preserved carcass. Thus, the lower DL value in the Brazilian Somali breed can be explained by the higher fat disposition rate, as indicated by its high value of fat thickness and carcass finish (Table 1). Normally, the slaughter houses in Brazil require a fat thickness (FT) of $3 \mathrm{~mm}$ (Silva Sobrinho, 2001). Hence, finishing on irrigated pastures can help promote adequate FT in carcasses due to the fact that there is not a great DL in the carcasses of animals from different genotypes.

It is clear that the Brazilian Somali breed had better finishing than the other genotypes (Table 1). However, its FT did not differ from the Santa Inês breed. This can be attributed to the form of rating these two traits. While the degree of finishing is evaluated visually by the amount and distribution of fat throughout the carcass, the FT is measured in a specific location on the carcass, which in this case may be responsible for having an advantage over the visual assessment, since Santa Inês lambs have been associated to carcasses with lower fat (Cartaxo et al., 2011) unlike the Brazilian Somali breed (Fernandes Júnior, 2010).

Just as the body compact index $(\mathrm{kg} / \mathrm{cm})$, measured by the ratio between live weight at slaughter and body length (Sousa et al., 2009), the carcass compact index (CCI) and the leg compact index (LCI) are indicators of a greater or lesser meat production specialization by the genetic groups. In this study the Santa Inês, Brazilian Somali and F1 groups had statistically equal and superior means than the Morada Nova group. On the other hand, the better carcass conformation presented by Santa Inês and F1 genotypes is an indication that they have better muscle plane distribution over the skeleton. This is important at the time of marketing since carcasses with better conformation are more appreciated by slaughter houses, because theoretically they have better quality cuts and, consequently, greater market acceptance.

Although the Morada Nova breed presented a relatively lower performance than the other 
genotypes, this breed had carcass yields and fat thickness similar to those of the Santa Inês and F1groups and also presented carcass conformation and rib eye area similar to that of the Brazilian Somalis breed. It's concluded that no one group presented a higher or lower performance in all carcass traits analyzed. However, there was evidence of greater specialization for meat production of the Santa Inês, Brazilian Somali and 1/2 Dorper - 1/2 Morada Nova genotypes when compared to the Morada Nova breed, since these genotypes have higher carcass weights and higher carcass compact index.

In general, the breed effect on carcass traits were expressed due to inherent differences in each genetic group such as adult size, precocity and distribution of fat deposits, as presented by the differences in internal carcass length and leg length and differences on carcass finishing degree (Table 1). These results are in accordance with Sanudo et al. (1997), who evaluated the carcass traits per breed and meat quality in three local Spanish breeds (Churra, Castellana and Manchega), as well as the crossbreed Awassi and reported these same differences between genotypes.

According to Lôbo et al. (2012) the Morada Nova breed originated from Portuguese and Spanish genetic groups and from breeds brought over from Africa during the slave trade. The Santa Inês breed was developed from unplanned crosses, which included Morada Nova animals and the Brazilian Somali breed, originating from the Black-Head Persian breed, which was brought to Brazil in more recent years (1939). Apart from differences in origin, these genotypes present differences in growth (Araújo Filho et al., 2010; Fernandes Júnior, 2010) which indicate genetic differences among them. In fact, Lôbo et al. (2012) reported that the Brazilian Somali breed has a distinct expression pattern compared to these groups, as well as the MyoD1 (Myogenic differentiation 1) gene expression that positively correlates with the cold carcass yield. This helps to explain the superiority of Brazilian Somali lambs in relation to carcass yields, when compared to the other genetic groups analyzed.

There were no significant differences between the Santa Inês, Brazilian Somali and F1 genotypes in the evaluation of commercial cuts in regards to the leg, loin, rib, breast and neck weights (Table 2). This is consistent with the fact that these genotypes did not differ in carcass weight (Table 1). However, there was genotype effect on the morphometric measurements taken from the carcass half (Table 1) and that should be seen in the weight differences in carcasses and cuts, since larger animals tend to be heavier.

Table 2. Least-square means and respective standard errors for weight of commercial cuts and its yields in relation to reconstituted half carcass

\begin{tabular}{|c|c|c|c|c|c|}
\hline & \multicolumn{4}{|c|}{ Genetic Group } & \multirow{2}{*}{$\mathrm{CV}(\%)$} \\
\hline & Santa Inês & Somalis & Morada Nova & F1 & \\
\hline \multicolumn{6}{|c|}{ Weight (Kg) } \\
\hline Leg & $1.79 \pm 0.09 \mathrm{a}$ & $1.60 \pm 0.12 \mathrm{a}$ & $1.01 \pm 0.13 \mathrm{~b}$ & $1.52 \pm 0.12 \mathrm{a}$ & 21.11 \\
\hline Loin & $0.39 \pm 0.03 a$ & $0.39 \pm 0.04 \mathrm{a}$ & $0.26 \pm 0.04 b$ & $0.35 \pm 0.04 \mathrm{ab}$ & 29.77 \\
\hline Rib & $0.49 \pm 0.03 \mathrm{a}$ & $0.39 \pm 0.04 \mathrm{ab}$ & $0.29 \pm 0.05 b$ & $0.43 \pm 0.04 \mathrm{a}$ & 27.49 \\
\hline Breast & $1.32 \pm 0.08 \mathrm{a}$ & $1.21 \pm 0.11 \mathrm{a}$ & $0.76 \pm 0.12 b$ & $1.26 \pm 0.11 \mathrm{a}$ & 24.01 \\
\hline Shoulder & $0.93 \pm 0.05 \mathrm{a}$ & $0.59 \pm 0.07 b c$ & $0.53 \pm 0.08 c$ & $0.74 \pm 0.07 b$ & 26.10 \\
\hline Neck & $0.36 \pm 0.02 \mathrm{a}$ & $0.31 \pm 0.03 \mathrm{ab}$ & $0.23 \pm 0.03 b$ & $0.34 \pm 0.03 \mathrm{a}$ & 26.54 \\
\hline \multicolumn{6}{|c|}{ Yield $(\%)$} \\
\hline Leg & $34.09 \pm 0.61 \mathrm{ab}$ & $35.54 \pm 0.83 \mathrm{a}$ & $32.93 \pm 0.90 b$ & $32.89 \pm 0.83 b$ & 6.50 \\
\hline Loin & $7.40 \pm 0.33 b$ & $8.64 \pm 0.45 a$ & $8.47 \pm 0.48 \mathrm{ab}$ & $7.29 \pm 0.45 b$ & 15.90 \\
\hline Rib & $9.32 \pm 0.35 \mathrm{a}$ & $8.71 \pm 0.47 \mathrm{a}$ & $9.22 \pm 0.51 \mathrm{a}$ & $9.15 \pm 0.47 \mathrm{a}$ & 13.60 \\
\hline Breast & $24.94 \pm 0.52 b$ & $27.08 \pm 0.71 \mathrm{a}$ & $24.53 \pm 0.76 b$ & $26.93 \pm 0.71 \mathrm{a}$ & 7.40 \\
\hline Shoulder & $17.47 \pm 0.49 \mathrm{a}$ & $13.23 \pm 0.66 b$ & $17.04 \pm 0.72 \mathrm{a}$ & $16.37 \pm 0.66 \mathrm{a}$ & 11.30 \\
\hline Neck & $6.79 \pm 0.28 b$ & $6.79 \pm 0.38 \mathrm{ab}$ & $7.82 \pm 0.4 \mathrm{a}$ & $7.37 \pm 0.38 \mathrm{ab}$ & 11.00 \\
\hline
\end{tabular}

Means in row followed by same letter do not differ by t test $(\mathrm{p}>0.05)$; F1 $=1 / 2$ Dorper $-1 / 2$ Morada Nova; CV $=$ coefficient of variation. 
Nevertheless, examining Table 1 it can be seen that the differences found in linear carcass measurements are not expressive and, furthermore, the leg circumference measurement, which provides an indication of the differences between the groups as to meat deposition in the carcass, was equivalent among the Santa Inês, Brazilian Somali and F1 genotypes. This helps to explain the fact that the Santa Ines breed, even with a higher slaughter weight when compared to other genotypes, did not maintain the same proportion to the differences in the weight of the carcass and the commercial cuts.

According to Cezar and Sousa (2007), in a scientific evaluation for comparison, the absolute weight of each cut in kilograms is less important than its relative weight in percentage. In this study, the similarity in the weight of the cuts of the Santa Inês, Somalis Brasileira and 1/2 Dorper - $1 / 2$ Morada Nova groups wasn't maintained in the yields. This indicates differences in the meat deposition in specific cuts among the groups.

The $\mathrm{pH}$, color, water holding capacity (WHC), cooking losses (CL) and shear force (CF) meat quality traits were evaluated. After slaughter the $\mathrm{pH}$ follows a downward trend, caused by the buildup of lactic acid resulting from chemical reactions post-mortem. Thus, the final $\mathrm{pH}$, as well as the speed of its decline, has great influence on the meat quality (Bressan et al., 2001). This can modify characteristics such as color, water holding capacity and tenderness, in addition to altering the organoleptic characteristics (Bonagurio et al., 2003). In this study, a sharp decrease in the $\mathrm{pH} 24$ value when compared to the $\mathrm{pH} 0$ value, with normal values for the species, was observed in all genetic groups analyzed. This indicates that the well-being of the animal ante mortem was preserved.

According to some authors (Bonagurio et al., 2003; Souza et al., 2004; Zeola et al., 2007), color is the most important trait for the consumer at the time of purchase, reflecting the chemical state and content of myoglobin in the muscle. In this study, the Brazilian Somali breed presented less redness when compared to Morada Nova. There were no significant differences in other comparisons between the genotypes studied (Tab. 3; P> 0.05).

Among the attributes related to the acceptance of meat, tenderness determines the acceptance of the cut (Souza et al., 2004) and cooking losses (CL) are associated with the meat yield at the time of consumption and is influenced by its water holding capacity (Bressan et al., 2001). In this study, the Brazilian Somali breed had higher cooking losses, significantly differing only from Santa Ines $(\mathrm{P}<0.05)$. This may be related to the fact that Brazilian Somali usually have a higher rate of fat deposition when compared to the other groups analyzed here. According to Pardi et al. (1993), the fat present in the meat is melted by the heat, which is also registered as cooking loss.

Table 3. Least-square means and respective standard errors for initial $\mathrm{pH}(\mathrm{pH} 0)$, final $\mathrm{pH}(\mathrm{pH} 24)$, color $\left(\mathrm{L}^{*}, \mathrm{a}^{*}\right.$ and $\left.\mathrm{b}^{*}\right)$, water holding capacity (WHC), cooking loss (CL) and shear force (SF) in different genetic groups of lambs finished in irrigated pastures

\begin{tabular}{|c|c|c|c|c|c|}
\hline & \multicolumn{4}{|c|}{ Genetic group } & \multirow{2}{*}{$\mathrm{CV} \%$} \\
\hline & Santa Inês & Somalis & Morada Nova & $\mathrm{F} 1$ & \\
\hline $\mathrm{pH} 0$ & $6.59 \pm 0.07$ & $6.61 \pm 0.10$ & $6.75 \pm 0.11$ & $6.66 \pm 0.10$ & 4.02 \\
\hline $\mathrm{pH} 24$ & $5.42 \pm 0.05$ & $5.36 \pm 0.07$ & $5.25 \pm 0.08$ & $5.37 \pm 0.07$ & 3.53 \\
\hline $\mathrm{L}^{*}$ & $35.25 \pm 1.02$ & $36.51 \pm 1.39$ & $37.07 \pm 1.50$ & $37.09 \pm 1.39$ & 10.15 \\
\hline$a^{*}$ & $12.67 \pm 0.29 \mathrm{ab}$ & $12.11 \pm 0.39 b$ & $13.67 \pm 0.42 \mathrm{a}$ & $13.07 \pm 0.39 \mathrm{ab}$ & 8.10 \\
\hline$b^{*}$ & $4.72 \pm 0.31$ & $5.14 \pm 0.42$ & $5.57 \pm 0.45$ & $5.21 \pm 0.42$ & 21.75 \\
\hline WHC (\%) & $71.56 \pm 1.16$ & $73.29 \pm 1.58$ & $75.08 \pm 1.87$ & $70.98 \pm 1.58$ & 5.78 \\
\hline CL (\%) & $26.14 \pm 0.95 b$ & $29.74 \pm 1.30 \mathrm{a}$ & $28.19 \pm 1.40 \mathrm{ab}$ & $27.47 \pm 1.30 \mathrm{ab}$ & 12.47 \\
\hline $\mathrm{SF}\left(\mathrm{kgf} / \mathrm{cm}^{2}\right)$ & $2.12 \pm 0.14$ & $2.05 \pm 0.18$ & $1.84 \pm 0.20$ & $2.25 \pm 0.18$ & 23.43 \\
\hline
\end{tabular}

Means in row followed by same letter do not differ by $\mathrm{t}$ test $(\mathrm{p}>0.05)$

$\mathrm{F} 1=1 / 2$ Dorper $\mathrm{x} 1 \frac{1}{2}$ Morada Nova; $\mathrm{CV}=$ coefficient of variation; $\mathrm{L}^{*}$ : lightness of meat; $\mathrm{a}^{*}$ : redness of meat; $\mathrm{b}^{*}$ : yellowness of meat. 
Rodrigues et al. (2008) reported values ranging from $58.5 \%$ to $62.5 \%$ for WHC and from $19.2 \%$ to $22.5 \%$ for CL in Santa Inês lambs. Zeola et al. (2007) observed variations from $55.52 \%$ to $59.06 \%$ for WHC in Morada Nova lambs. The higher WHC of this study can be attributed to the differences in methodology and type of finishing, confinement and pasture. This aspect was demonstrated by Santos-Silva et al. (2002), who found higher WHC values in White Merino and crossbred Ile de France - White Merino under grazing when compared to confined animals.

The meat tenderness can be defined as the ease of chewing, with sensations of penetration, cutting and breaking strength (Pinheiro et al., 2009). Its evaluation is made by shear force (SF), which has been used due to high correlation with sensory analysis. In this study, the values observed can be classified as presenting soft texture, according to the classification proposed by Bickerstaffe et al. (1997), who rated the meat texture as soft (up to $8.6 \mathrm{kgf} / \mathrm{cm}^{2}$ ), acceptable (from 8 to $11 \mathrm{kgf} / \mathrm{cm}^{2}$ ) and hard (above $11 \mathrm{kgf} / \mathrm{cm}^{2}$ ).

According to Bressan et al. (2001), differences in SF values occur for many reasons, such as: ante mortem management, speed of rigor mortis, post mortem $\mathrm{pH}$, pre-slaughter temperature, beginning and extension of glycolysis, muscle used, postslaughter management (such as electrical stimulation and hot boning), storage conditions and methodology applied - such as temperature and time used in the cooking process. It is noteworthy to mention that no studies on meat quality were found in literature with these breeds under the same management conditions employed in this study in order to provide a better comparison of results. Moreover, in this study, there were no significant differences between genotypes. In addition, low coefficients of variation and low standard errors indicate little variability in responses, which is consistent with Santos-Silva et al. (2002). According to these authors, in most studies, the genotype has not been associated with important differences in the quality of lamb meat. However, few studies were conducted under semiarid conditions (Sen et al., 2004).

\section{CONCLUSIONS}

For the management conditions employed in this study, there was evidence of greater specialization for meat production of the Santa Inês, Brazilian Somalis and $1 / 2$ Dorper - 1/2 Morada Nova genotypes when compared to the Morada Nova breed. However, there are no substantial differences between the groups regarding meat quality.

\section{ACKNOWLEDGEMENTS}

The authors acknowledge Embrapa for the financial support. The first author thanks "Fundação Cearense de Apoio ao Desenvolvimento Científico e Tecnológico FUNCAP" and "Universidade Federal do Ceará" for the scholarship.

\section{REFERENCES}

ABULARACH, M.L.S.; ROCHA, C.E.; FELÍCIO, P.E. Características de qualidade do contrafilé (Longissimus dorsi) de touros jovens da raça Nelore. Cienc. Tecnol. Aliment., v.18, p.205-210, 1998.

ARAÚJO FILHO, J.T.; COSTA, R.G.; FRAGA, A.B. et al. Desempenho e composição da carcaça de cordeiros deslanados terminados em confinamento com diferentes dietas. Rev. Bras. Zootec., v.39, p.363-371, 2010.

BICKERSTAFFE, R.; Le COUTEUR, C.E.; MORTON, J.D. Consistency of tenderness in New Zealand retail meat. In: INTERNATIONAL CONGRESS OF MEAT SCIENCE TECHNOLOGY, 43., 1997,Auckland. Anais...Auckland: ICOMST , 1997. p.196-197.

BONAGURIO, S.; PÉREZ, J.R.O.; GARCIA, I.F.F. et al. Qualidade da Carne de Cordeiros Santa Inês Puros e Mestiços com Texel Abatidos com Diferentes Pesos. Rev. Bras. Zootec., v.32, p.1981-1991, 2003.

BRESSAN, M.C.; PRADO, O.V.; PÉREZ, J.R. et al. Efeito do peso ao abate de cordeiros Santa Inês e Bergamácia sobre as características físicoquímicas da carne. Cienc. Tecnol. Aliment., v.31, p.293-303, 2001. 
CARTAXO, F.Q.; SOUSA, W.H.; COSTA, R.G. et al. Características quantitativas da carcaça de cordeiros de diferentes genótipos submetidos a duas dietas. Rev. Bras. Zootec., v.40, p.22202227, 2011.

CEZAR, M.F.; SOUZA, W.H. Carcaças ovinas e caprinas: obtenção, avaliação e classificação. Uberaba: Editora Agropecuária Tropical, 2007. 231p.

DUCKETT, S.K.; KLEIN, T.A.; LECKIE, R.K. et al. Effect of freezing on calpastatin activity and tenderness of callipyge Lamb. J. Anim. Sci., v.76, p.1869-1874, 1998.

FERNANDES JÚNIOR, G.A. Desempenho produtivo e qualidade da carne de ovinos terminados em pastagem irrigada no semiárido nordestino. 2010. 88f. Dissertação (Mestrado em Zootecnia) - Produção e Melhoramento Animal, Universidade Federal do Ceará, Fortaleza.

GRAU, W.R.; HAMM, R. Muscle as food. In: P.J. Bechtel (ed.). Food Science and Technology. A Series of Monographs. New York: Academic Press, 1953. 54p.

HONIKEL, K.O. Reference methods for the assessment of physical characteristics of meat. Meat Sci., v.49, p.447-457, 1998.

LÔBO, A.M.B.O.; GUIMARÃES, S.E.F.; PAIVA, S.R. et al. Differentially transcribed genes in skeletal muscle of lambs. Livest. Sci., v.150, p.31-41, 2012.

OKEUDO, N.J.; MOSS, B.W. Interrelationships amongst carcass and meat quality characteristics of sheep. Meat Sci., v.69, p.1-8, 2005.

PARDI, M.C.; SANTOS, I.F.; SOUZA, E.R.; PARDI, S.H. Ciência, higiene e tecnologia da carne: tecnologia da sua obtenção $e$ transformação. Goiânia: Centro Editorial e Gráfico Universidade de Goiás, v.1, 1993. 586p.

PINHEIRO, R.S.B.; SILVA SOBRINHO, A.G.; SOUZA, H.B.A.; YAMAMOTO, S.M. Qualidade de carnes provenientes de cortes da carcaça de cordeiros e de ovinos adultos. Rev. Bras. Zootec., v.38, p.1790-1796, 2009.
RODRIGUES, G.H.; SUSIN, I.; PIRES, A.V. et al. Polpa cítrica em rações para cordeiros em confinamento: características da carcaça e qualidade da carne. Rev. Bras. Zootec., v.37, p.1869-1875, 2008.

SANTOS-SILVA, J.; MENDES, I.A.; BESSA, R.J.B. The effect of genotype, feeding system and slaughter weight on the quality of light lambs 1. Growth, carcass composition and meat quality. Livest. Prod. Sci., v.76, p.17-25, 2002.

SAÑUDO, C.; CAMPO, M.M.; SIERRA, I. et $a l$. Breed effect on carcase and meat quality of suckling lambs. Meat Sci., v.46, p.357-365, 1997.

SEN, A.R.; SANTRA, A.; KARIM, S.A. Carcass yield, composition and meat quality attributes of sheep and goat under semiarid conditions. Meat Sci., v.66, p.757-763, 2004.

SILVA SOBRINHO, A.G. Body composition and characteristics of carcass from lambs of different genotypes and ages at slaughter. 1999. 54f. (PostDoctorate in Sheep Meat Production) Massey University, Palmerston North, 1999.

SILVA SOBRINHO, A.G. Criação de ovinos. 2.ed. Jaboticabal: Funep, 2001. 302p.

SOUSA, W.H.; BRITO, E.A.; MEDEIROS, A.N. et al. Características morfométricas e de carcaça de cabritos e de cordeiros terminados em confinamento. Rev. Bras. Zootec., v.38, p.13401346, 2009.

SOUZA, X.R.; BRESSAN, M.C.; PÉREZ, J.R.O. et al. Efeitos do grupo genético, sexo e peso ao abate sobre as propriedades físicoquímicas da carne de cordeiros em crescimento. Cienc. Tecnol. Aliment., v.24, p.543-549, 2004.

STATISTICAL Analysis Sistem - SAS Institute Inc SAS/STAT., 1996. User's Guide,v. 6.11. 4.ed., v.2. SAS Institute Inc., Cary, 842 pp.

ZEOLA, N.M.B.L.; SOUZA, P.A.; SILVA SOBRINHO, A.G.; BARBOSA, J.C. Cor, capacidade de retenção de água e maciez da carne de cordeiro maturada e injetada com cloreto de cálcio. Arq. Bras. Med. Vet. Zootec., v.59, p.1058-1066, 2007. 